\title{
The methylation of benzoic and n-butyric acids by chloromethane in Phellinus pomaceus
}

\author{
Kieran J. McNally, ${ }^{1}$ John T. G. Hamilton ${ }^{2}$ and David B. HaRPer ${ }^{1,2 *} \dagger$ \\ ${ }^{1}$ Department of Food and Agricultural Chemistry, The Queen's University of Belfast, Newforge Lane, Belfast BT9 5PX, UK \\ ${ }^{2}$ Food and Agricultural Chemistry Research Division, Department of Agriculture for Northern Ireland, Newforge Lane, \\ Belfast BT9 5PX, UK
}

(Received 22 February 1990; revised 24 April 1990; accepted 4 May 1990)

\begin{abstract}
The kinetics of carboxylic acid methylation by chloromethane $\left(\mathrm{CH}_{3} \mathrm{Cl}\right)$ in mycelia of the fungus Phellinus pomaceus were examined. Substantial incorporation of $\mathrm{C}^{2} \mathrm{H}_{3}$ - into ester was observed within 5 min of addition of $\mathrm{C}^{2} \mathrm{H}_{3} \mathrm{Cl}$ to washed mycelia in the presence of the non-physiological acceptor butyric acid, rendering it unlikely that $\mathrm{CH}_{3} \mathrm{Cl}$ was converted to a diffusible intermediate before acting as methyl donor. The rate of methyl butyrate biosynthesis attained a maximum of $0.14 \mu \mathrm{mol} \mathrm{g} \mathrm{g}^{-1} \mathrm{~h}^{-1}$ at $1.5 \mathrm{mM}$-butyric acid, with higher concentrations causing increasing inhibition. Exogenous $\mathrm{CH}_{3} \mathrm{Cl}$ did not affect methyl butyrate production implying that the rate of $\mathrm{CH}_{3} \mathrm{Cl}$ biosynthesis did not limit methylation. However, $\mathrm{C}^{2} \mathrm{H}_{3}$-incorporation from exogenous $\mathrm{C}^{2} \mathrm{H}_{3} \mathrm{Cl}$ into methyl butyrate rose sharply from 20 to $60 \%$ between 1.5 and $4 \mathrm{mM}$-butyric acid, suggesting inhibition of $\mathrm{CH}_{3} \mathrm{Cl}$ biosynthesis by the acid, an interpretation supported by the rapid decline in gaseous $\mathrm{CH}_{3} \mathrm{Cl}$ release by mycelia between 1.5 and 2 mM-butyric acid. With the natural acceptor benzoic acid as substrate a significant increase in the rate of ester biosynthesis was obtained in the presence of exogenous $\mathrm{CH}_{3} \mathrm{Cl}$. Ester biosynthesis was maximal $\left(0.18 \mu \mathrm{mol} \mathrm{g}^{-1} \mathrm{~h}^{-1}\right)$ at $0.5 \mathrm{mM}$-benzoic acid but fell extremely rapidly with increasing concentration. As with butyric acid supraoptimal concentrations halted $\mathrm{CH}_{3} \mathrm{Cl}$ release and increased $\mathrm{C}^{2} \mathrm{H}_{3}$-incorporation from exogenous $\mathrm{C}^{2} \mathrm{H}_{3} \mathrm{Cl}$. Studies on $\mathrm{C}^{2} \mathrm{H}_{3}$-incorporation from exogenous $\mathrm{C}^{2} \mathrm{H}_{3} \mathrm{Cl}$ into ester revealed a linear relationship between the logarithm of the percentage $\mathrm{C}^{2} \mathrm{H}_{3}$-incorporation and the logarithm of $\mathrm{C}^{2} \mathrm{H}_{3} \mathrm{Cl}$ concentration with both butyric and benzoic acids as substrate, suggesting that exogenous $\mathrm{C}^{2} \mathrm{H}_{3} \mathrm{Cl}$ competed with endogenously synthesized $\mathrm{CH}_{3} \mathrm{Cl}$ for adsorption at a solid interface, possibly a membrane within the cell, prior to reaction of the compound at the active site. When mycelia were grown in the presence of different halide ions, greater methylating activity was found in $\mathrm{Br}^{-}$- and $\mathrm{I}^{-}$-grown mycelia. The system had a higher affinity for $\mathrm{CH}_{3} \mathrm{Br}$ and $\mathrm{CH}_{3} \mathrm{I}$ as methyl donors than $\mathrm{CH}_{3} \mathrm{Cl}$. Fluoromethane was not a substrate for the methylating system nor did it act as a competitive inhibitor.
\end{abstract}

\section{Introduction}

The majority of species in the Hymenochaetaceae, a widespread family of wood-rotting bracket fungi, release gaseous chloromethane $\left(\mathrm{CH}_{3} \mathrm{Cl}\right)$ during secondary metabolism when grown in the presence of $\mathrm{Cl}^{-}$(Cowan et al., 1973, Harper, 1985; Harper \& Kennedy, 1986; Harper $e t$ al., 1988). Methyl esters of aromatic acids such as methyl benzoate and methyl furoate also occur extensively in such fungi (Collins \& Halim, 1972; Harper \& Kennedy, 1986; Harper et al., 1988). Ester formation appears to be biochemically linked with $\mathrm{CH}_{3} \mathrm{Cl}$ biosynthesis, as both processes are inhibited by thiocyanate (Harper \&

† Correspondence should be sent to the Queen's University address.
Kennedy, 1986) and methyl benzoate occurrence in the genus Phellinus is confined to $\mathrm{CH}_{3} \mathrm{Cl}$-producing species (Harper et al., 1988). Moreover, the patterns of $\mathrm{C}^{2} \mathrm{H}_{3}$ incorporation from [methyl- ${ }^{2} \mathrm{H}$ ]methionine into methyl benzoate and $\mathrm{CH}_{3} \mathrm{Cl}$ show striking similarities (Harper \& Hamilton, 1988).

Recently, Harper et al. (1989) demonstrated that $\mathrm{CH}_{3} \mathrm{Cl}$ can act as methyl donor for biosynthesis of methyl benzoate and methyl furoate in primary metabolism of $P$. pomaceus. Not only could the broad specificity methylating system esterify a wide range of aliphatic and aromatic acids but, in addition to $\mathrm{CH}_{3} \mathrm{Cl}$, both bromo- and iodomethanes could act as methyl donors. Butyric acid was found to be a particularly convenient substrate for assay of methylating activity in

0001-6108 (C) 1990 SGM 
mycelia. Neither methanol nor a coenzyme-A derivative appeared to be an intermediate in methylation.

Investigations revealed that the initial growth-related accumulation of methyl benzoate during culture of $P$. pomaceus was parallelled by a concomitant increase in activity of the methylating system in the mycelium. Changes in the incorporation of $\mathrm{C}^{2} \mathrm{H}_{3}$ - from exogenous $\mathrm{C}^{2} \mathrm{H}_{3} \mathrm{Cl}$ during growth indicated that, although utilization of $\mathrm{CH}_{3} \mathrm{Cl}$ was initially closely coupled to the biosynthesis of the compound, later in growth and during the idiophase the system became less tightly channelled. This phase coincided with the release of gaseous $\mathrm{CH}_{3} \mathrm{Cl}$ by the fungus. Hence, although $\mathrm{CH}_{3} \mathrm{Cl}$ ostensibly appears a typical secondary metabolite, its release in the idiophase would seem merely to reflect the breakdown of the strict coordination of biosynthesis and utilization which exists during the primary metabolic phase.

Methylation of compounds other than carboxylic acids by $\mathrm{CH}_{3} \mathrm{Cl}$ can also occur in $\mathrm{P}$. pomaceus. Thus a $\mathrm{CH}_{3} \mathrm{Cl}-$ utilizing system capable of methylating phenols and thiophenol has been identified in the fungus (Harper $e t$ $a l ., 1989)$. It was clearly biochemically distinct from the carboxylic acid methylating system in that maximum activity was attained in the idiophase. The observation that $\mathrm{C}^{2} \mathrm{H}_{3}$ - from $\mathrm{C}^{2} \mathrm{H}_{3} \mathrm{Cl}$ was incorporated into methyl benzoate by Fomitopsis pinicola, a non- $\mathrm{CH}_{3} \mathrm{Cl}$-releasing fungus from the family Polyporaceae, led Harper et al. (1989) to speculate that $\mathrm{CH}_{3} \mathrm{Cl}$ biosynthesis and utilization might not be confined to Hymenochaetaceous fungi but could be widely present in fungi and even higher plants. It was suggested that the compound may have escaped detection in such organisms hitherto because it is a chemically unreactive gas readily overlooked by normal analytical procedures and is synthesized and utilized in tightly channelled multienzyme complexes in which release of free $\mathrm{CH}_{3} \mathrm{Cl}$ is seldom or never observed.

In this paper we seek to define more precisely the kinetics of the carboxylic acid methylating system in the intact mycelium of $P$. pomaceus with particular reference to the effects of exogenous concentrations of methyl acceptor and methyl donor on the rate of methylation by the system. Additionally, the effects of these parameters on $\mathrm{C}^{2} \mathrm{H}_{3}$-incorporation from exogenous $\mathrm{C}^{2} \mathrm{H}_{3} \mathrm{Cl}$ into methyl esters and on the release of endogenously synthesized $\mathrm{CH}_{3} \mathrm{Cl}$ are described. In these studies the natural acceptor benzoic acid has been compared with the non-physiological acceptor butyric acid and chloro-, bromo- and iodomethane have been utilized as methyl donors.

\section{Methods}

Organisms and maintenance media. Phellinus pomaceus (Pers) Maire (NCWRF-FPRL 33A) was acquired from the National Collection of
Wood Rotting Fungi, Princes Risborough Laboratory, Building Research Establishment, Aylesbury, Bucks., UK. The fungus was maintained on slants of $5 \%(\mathrm{w} / \mathrm{v})$ malt extract agar (Oxoid) containing chloramphenicol $\left(25 \mu \mathrm{g} \mathrm{ml}^{-1}\right)$. Cultures used for inoculation were grown at $25^{\circ} \mathrm{C}$ for 3 weeks in $20 \mathrm{ml}$ vials with loosely fitting screw caps.

Chemicals. $\mathrm{C}^{2} \mathrm{H}_{3} \mathrm{~F}$ (99.9 atom\% $\left.{ }^{2} \mathrm{H}\right), \mathrm{C}^{2} \mathrm{H}_{3} \mathrm{Cl}\left(99.9\right.$ atom $\left.\%{ }^{2} \mathrm{H}\right)$, $\mathrm{C}^{2} \mathrm{H}_{3} \mathrm{Br}\left(99.5\right.$ atom $\left.\%{ }^{2} \mathrm{H}\right)$ and $\mathrm{C}^{2} \mathrm{H}_{3} \mathrm{I}\left(99.5\right.$ atom $\left.\%{ }^{2} \mathrm{H}\right)$ were purchased from MSD Isotopes, Montreal, Canada. Chloromethane and Agarose ' 10 ' Electran were obtained from BDH. Benzoic and butyric acids were acquired from Sigma.

Culture media and cultural conditions. The fungus was grown on glucose/mycological peptone/agarose medium overlaid with cellulose membrane and harvested as described by Harper et al. (1989). Where the use of $\mathrm{Cl}^{-}, \mathrm{Br}^{-}$or $\mathrm{I}^{-}$-grown mycelia is specified, mycelia were harvested from cultures grown in the presence of $10 \mathrm{mM}-\mathrm{NaCl}$, $10 \mathrm{mM}-\mathrm{NaBr}$ or $2 \mathrm{mM}-\mathrm{NaI}$ respectively.

Assay of methylating activity. Measurement of the rate of methylation of butyric and benzoic acids by $P$. pomaceus and the percentage $\mathrm{C}^{2} \mathrm{H}_{3}$-label incorporated into ester under various conditions was based on the standard assay procedure described by Harper et al. (1989), using as substrate $2 \mathrm{~mm}$-butyric acid or $0.5 \mathrm{~mm}$-benzoic acid and $1.23 \mathrm{mM}-\mathrm{C}^{2} \mathrm{H}_{3} \mathrm{Cl}$ as methyl donor. In some experiments the concentrations of benzoic and butyric acids were varied; in others the nature and concentration of the halomethane methyl donor were changed. In time-course studies the assay was initiated by simultaneous injection of carboxylic acid substrate and $\mathrm{C}^{2} \mathrm{H}_{3} \mathrm{Cl}$ into the vial and incubation periods of between $5 \mathrm{~min}$ and $14 \mathrm{~h}$ were employed. In investigations where the efficacy of $\mathrm{C}^{2} \mathrm{H}_{3} \mathrm{Cl}$ as methyl donor was compared with $\mathrm{C}^{2} \mathrm{H}_{3} \mathrm{Br}$ or $\mathrm{C}^{2} \mathrm{H}_{3}$ I quantities of halomethane injected into the vial were such as to achieve a final concentration in the aqueous phase of $0.25 \mathrm{~mm}$. In all experiments assays were done in triplicate and unless otherwise indicated the mean methylating activity was expressed as nmol ester formed ( $g$ fresh wt mycelium) $)^{-1} h^{-1}\left(n m o l ~ g^{-1} h^{-1}\right)$. All experiments were repeated at least twice and the results presented for each experiment in this paper are representative of those obtained.

Measurement of $\mathrm{CH}_{3} \mathrm{Cl}$ production by isolated mycelia. Mycelia (35 mg), prepared as described above, were suspended in $20 \mathrm{~mm}$ sodium citrate buffer $(\mathrm{pH} 4.0,2 \mathrm{ml})$, containing the appropriate concentration of butyric or benzoic acid, in $40 \mathrm{ml} \mathrm{screw-capped} \mathrm{septum}$ vials sealed with Teflon-lined silicone discs. After incubation at $25^{\circ} \mathrm{C}$ for $12 \mathrm{~h}$ samples $(2 \mathrm{ml})$ of headspace were withdrawn and $\mathrm{CH}_{3} \mathrm{Cl}$ was determined by gas chromatography are described by Harper et al. (1989).

Determination of methyl esters and $\mathrm{C}^{2} \mathrm{H}_{3}$-incorporation into methyl moiety. Methyl butyrate was measured in situ in the assay vial by gas chromatography using a headspace technique and conditions similar to those described for $\mathrm{CH}_{3} \mathrm{Cl}$ assay except that the oven temperature was programmed from 100 to $230^{\circ} \mathrm{C}$. The percentage of methyl butyrate labelled with $\mathrm{C}^{2} \mathrm{H}_{3}$ was determined using the purge and trap/mass spectrometric technique described by Harper et al. (1989). The percentage incorporation of $\mathrm{C}^{2} \mathrm{H}_{3}$ - into methyl butyrate was determined as the ratio of ion currents $\frac{m / e 77}{m / e 74+m / e 77} \times 100$ at the normal retention time of methyl butyrate. As an additional check the ratio of ion currents $\frac{m / e 90}{m / e 87+m / e 90}$ was also measured. As some fractionation of deuterated methyl ester from non-deuterated ester occurred during chromatography, ion currents at each mass were determined by integration of the whole area of the partially resolved ester peak. Percentage incorporation is presented as the mean of measurements made on the three replicate vials used in each assay. 
Methyl benzoate in assay solutions was determined by gas chromatography/mass spectrometry using the following procedure. A sample $(1 \mathrm{ml})$ was placed in a $20 \mathrm{ml}$ vial sealed with a crimped cap and septum-lined with PTFE, and equilibrated at $41^{\circ} \mathrm{C}$ in a Hewlett Packard 19395A Headspace Sampler directly linked to an HP5890 gas chromatograph interfaced with an HP5970 Mass Selective Detector system under the control of an HP Chem Station. Headspace $(1 \mathrm{ml})$ was injected via a transfer line heated at $150^{\circ} \mathrm{C}$ and a gas chromatograph injection port maintained at $250^{\circ} \mathrm{C}$ on to an Ultra 2 WCOT capillary column $(25 \mathrm{~m} \times 0.22 \mathrm{~mm}$ i.d.) with $5 \%$ diphenyl $/ 95 \%$ dimethylpolysiloxane as bonded phase $(0 \cdot 33 \mu \mathrm{m})$. A split ratio of $15: 1$ was used and the oven programmed from 40 to $200^{\circ} \mathrm{C}$ at $10^{\circ} \mathrm{C} \mathrm{min}-1$ with helium as carrier gas at a flow rate of $1 \mathrm{ml} \mathrm{min}{ }^{-1}$. The Mass Selective Detector was operated in the selected ion monitoring mode and the sum of the ion currents at $m / e 136$ and $m / e 139$ at the retention time of methyl benzoate was compared to a calibration graph obtained using authentic compound. The percentage incorporation of $\mathrm{C}^{2} \mathrm{H}_{3}$ - was measured as the ratio of the ion currents $\frac{m / e 139}{m / e 136+m / e 139}$ determined, as with methyl butyrate, by integration of the whole area of the partially resolved ester peak. Results are expressed as a mean of the three replicates.

\section{Results and Discussion}

\section{Time course of methylation in washed mycelia}

When washed mycelia were incubated with $2 \mathrm{mM}$ butyric acid in the presence of $1.23 \mathrm{~mm}-\mathrm{C}^{2} \mathrm{H}_{3} \mathrm{Cl}$, the rate of methyl butyrate production remained constant at approximately $0.15 \mu \mathrm{mol} \mathrm{g}^{-1} \mathrm{~h}^{-1}$ over the entire $14 \mathrm{~h}$ period studied. $\mathrm{C}^{2} \mathrm{H}_{3}$-label was incorporated into the methyl moiety of methyl butyrate to the extent of $17 \%$ after $5 \mathrm{~min}$, this duration being the minimum incubation time at which methyl butyrate could be detected in the assay mixture using the gas chromatography/mass spectrometric assay procedure. $\mathrm{C}^{2} \mathrm{H}_{3}$-incorporation into ester rose rapidly during further incubation reaching within $1 \mathrm{~h}$ a plateau value of approximately $40 \%$ which was maintained for the remainder of the incubation period. Methyl benzoate biosynthesis from $0.5 \mathrm{~mm}$ benzoic acid followed a similar course with a rate of ester formation of $0.21 \mu \mathrm{mol} \mathrm{g}^{-1} \mathrm{~h}^{-1}$ though incorporation of $\mathrm{C}^{2} \mathrm{H}_{3}$ - into the compound stabilized after $1 \mathrm{~h}$ at a somewhat lower value of $20 \%$. These observations, in particular the speed with which label was incorporated, and the short period which elapsed before attainment of maximum labelling of ester render it improbable that $\mathrm{CH}_{3} \mathrm{Cl}$ undergoes conversion to methanol or indeed any freely diffusible intermediate before acting as a substrate for the methylating system, in confirmation of earlier observations (Harper et al., 1989). Only if the endogenous cellular pool of the putative intermediate was of negligible size could label be incorporated with the rapidity observed. The interval of $5 \mathrm{~min}$ before detection of labelled methyl butyrate probably represents the period necessary for $\mathrm{C}^{2} \mathrm{H}_{3} \mathrm{Cl}$ and butyric acid to diffuse

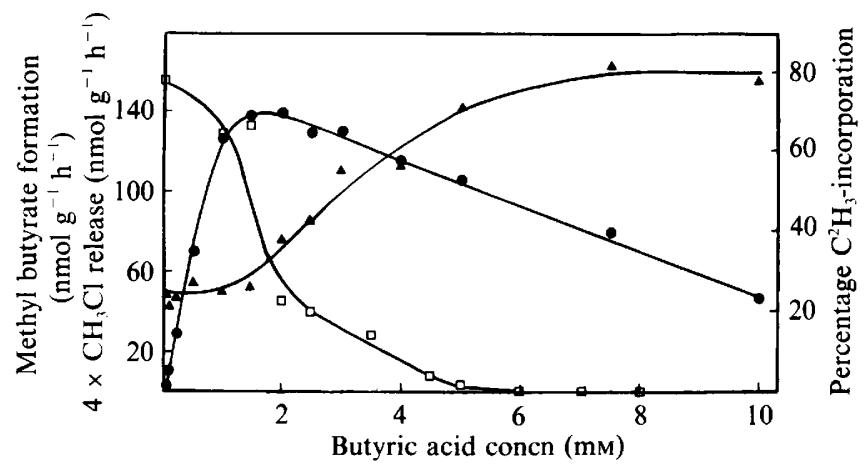

Fig. 1. Effect of butyric acid concentration on methyl butyrate formation, incorporation of $\mathrm{C}^{2} \mathrm{H}_{3}$-label from exogenous $\mathrm{C}^{2} \mathrm{H}_{3} \mathrm{Cl}$ and $\mathrm{CH}_{3} \mathrm{Cl}$ release by washed mycelia of $P$. pomaceus. Washed mycelia were incubated for $12 \mathrm{~h}$ as described in Methods with $1.23 \mathrm{mM}-\mathrm{C}^{2} \mathrm{H}{ }_{3} \mathrm{Cl}$ and different concentrations of butyric acid. Methyl butyrate formation and incorporation of $\mathrm{C}^{2} \mathrm{H}_{3}$-label into the ester were measured. In a separate experiment mycelia of the same origin were incubated for $12 \mathrm{~h}$ as described in Methods in sodium citrate buffer $(20 \mathrm{mM}, \mathrm{pH} 4 \cdot 0)$ with different concentrations of butyric acid and $\mathrm{CH}_{3} \mathrm{Cl}$ released by the mycelia was determined by gas chromatography. Methyl butyrate production; $\Delta$, percentage of methyl butyrate labelled with $\mathrm{C}^{2} \mathrm{H}_{3^{-}}$; $\square, \mathrm{CH}_{3} \mathrm{Cl}$ released by mycelia.

to the cellular location of the methylating enzyme and for $\mathrm{C}^{2} \mathrm{H}_{3} \mathrm{Cl}$ to displace endogenous $\mathrm{CH}_{3} \mathrm{Cl}$ in competition for the active site, although obviously a finite time is also required for the labelled compound to accumulate to detectable levels.

\section{Effect of carboxylic acid concentration on methyl ester biosynthesis and $\mathrm{CH}_{3} \mathrm{Cl}$ release}

Methyl butyrate production attained a maximum between 1.5 and 2 mM-butyric acid and higher concentrations of the compound caused increasing inhibition (Fig. 1). Although not illustrated, the curve obtained in the absence of exogenous $\mathrm{C}^{2} \mathrm{H}_{3} \mathrm{Cl}$ exhibited no significant difference from that obtained in its presence, indicating that the rate of endogenous $\mathrm{CH}_{3} \mathrm{Cl}$ biosynthesis did not limit the rate of methylation at any concentration of butyric acid studied. This observation supports, over a wider range of concentrations, the tentative conclusions of Harper et al. (1989) based on limited data gathered at two concentrations of butyric acid. Significantly, incorporation of $\mathrm{C}^{2} \mathrm{H}_{3}$ - into methyl butyrate, although at a constant level of about $20 \%$ up to $1.5 \mathrm{mM}$-butyric acid rose sharply to $60 \%$ between 1.5 and $4 \mathrm{mM}$, a concentration range in which the rate of ester biosynthesis showed very little change. Incorporation eventually stabilized at about $80 \%$ at concentrations above $8 \mathrm{~mm}$. One possible explanation of this rapid increase is that endogenous $\mathrm{CH}_{3} \mathrm{Cl}$ biosynthesis is inhibited by higher concentrations of butyric acid and 
that the active site of the methylating enzyme therefore becomes increasingly more accessible to exogenous $\mathrm{C}^{2} \mathrm{H}_{3} \mathrm{Cl}$. To test this hypothesis, the change in the rate of release of $\mathrm{CH}_{3} \mathrm{Cl}$ from the mycelium when incubated in the absence of $\mathrm{C}^{2} \mathrm{H}_{3} \mathrm{Cl}$ at various butyric acid concentrations was studied (Fig. 1). A very marked decline in gaseous $\mathrm{CH}_{3} \mathrm{Cl}$ production was evident between 1.5 and $2 \mathrm{mM}$, exactly coincident with the butyric acid concentration range at which incorporation into methyl butyrate begins to increase. This virtual cessation of $\mathrm{CH}_{3} \mathrm{Cl}$ release almost certainly betokens a real reduction in the overall rate of biosynthesis, sufficient to allow exogenous $\mathrm{C}^{2} \mathrm{H}_{3} \mathrm{Cl}$ increased access to the methylating site and to result in greater $\mathrm{C}^{2} \mathrm{H}_{3}$-incorporation. Clearly, however, this inhibition does not restrict endogenous $\mathrm{CH}_{3} \mathrm{Cl}$ biosynthesis enough for the rate of methylation in the absence of exogenous halomethane to be limited by the endogenous supply of $\mathrm{CH}_{3} \mathrm{Cl}$.

The effect of the concentration of benzoic acid, the main natural substrate for the methylating system, on the rate of methyl benzoate biosynthesis differs from that of butyric acid on methyl butyrate biosynthesis in a number of important respects (Fig. 2a). Firstly, a small but significant increase in the rate of methyl benzoate synthesis was obtained in the presence of exogenous $\mathrm{C}^{2} \mathrm{H}_{3} \mathrm{Cl}$ (see also Fig. 3), suggesting some limitation of methylation by the endogenous rate of $\mathrm{CH}_{3} \mathrm{Cl}$ synthesis, particularly at higher benzoic acid concentrations. Secondly, the optimum concentration of benzoic acid for ester biosynthesis was $0.5 \mathrm{~mm}$ and the rate of biosynthesis fell rapidly at higher concentrations to the extent that at $2 \mathrm{~mm}$ it was only about $17 \%$ of the maximum rate, indicating powerful inhibition of the methylating system, probably of an allosteric nature. The inhibitory effect of supraoptimal concentrations of benzoic acid was even more clearly evident when the effect of different benzoic acid concentrations on the rate of methyl butyrate synthesis from butyric acid at the optimum concentration of the latter, i.e. $2 \mathrm{~mm}$, was examined in a separate experiment: at $0,0.1,0.5$ and 2.0 mM-benzoic acid the rates of methyl butyrate biosynthesis were $277,368,282$ and $2 \mathrm{nmol} \mathrm{g}^{-1} \mathrm{~h}^{-1}$ respectively. There would appear from these values to be some indication of benzoic acid having an activatory influence at $0 \cdot 1 \mathrm{mM}$, although further investigations will be required to define the effect accurately.

Despite these differences regarding its effect on ester biosynthesis, benzoic acid behaved similarly to butyric acid in that concentrations greater than the optimum caused a marked reduction of $\mathrm{CH}_{3} \mathrm{Cl}$ release which was associated with a concomitant increase in $\mathrm{C}^{2} \mathrm{H}_{3}$ incorporation from exogenous $\mathrm{C}^{2} \mathrm{H}_{3} \mathrm{Cl}$ (Fig. 2b). Again, inhibition of endogenous $\mathrm{CH}_{3} \mathrm{Cl}$ biosynthesis appears the most likely explanation.
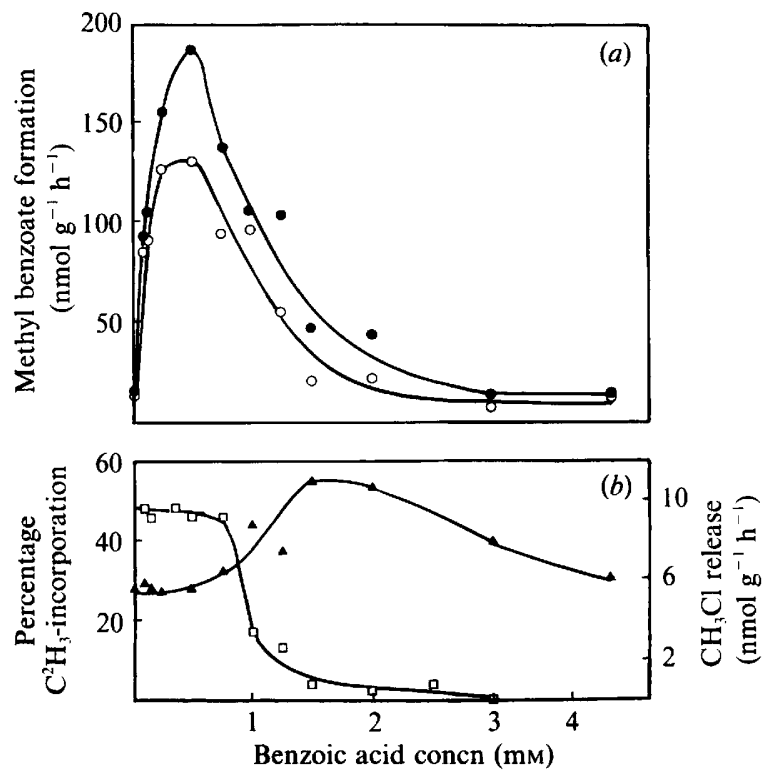

Fig. 2. Effect of benzoic acid concentration on (a) production of methyl benzoate in the presence and absence of $\mathrm{C}^{2} \mathrm{H}_{3} \mathrm{Cl}$ and (b) incorporation of $\mathrm{C}^{2} \mathrm{H}_{3}$-label into methyl benzoate and release of $\mathrm{CH}_{3} \mathrm{Cl}$ by washed mycelia of $P$. pomaceus. Washed mycelia were incubated for $12 \mathrm{~h}$ as described in Methods with different concentrations of benzoic acid in the presence and absence of $\mathrm{C}^{2} \mathrm{H}_{3} \mathrm{Cl}$ (1.23 mM). Methyl benzoate formation and incorporation of $\mathrm{C}^{2} \mathrm{H}_{3}$ - into ester were measured. In a separate experiment mycelia of the same origin were incubated for $12 \mathrm{~h}$ as described in Methods in sodium citrate buffer ( $20 \mathrm{mM}, \mathrm{pH} 4.0)$ with different concentrations of benzoic acid, and $\mathrm{CH}_{3} \mathrm{Cl}$ released was measured by gas chromatography. $O$, Methyl benzoate production in the absence of exogenous $\mathrm{C}^{2} \mathrm{H}_{3} \mathrm{Cl}$; -, methyl benzoate production in the presence of $1.23 \mathrm{mM}-\mathrm{C}^{2} \mathrm{H}_{3} \mathrm{Cl}$; $\Delta$, percentage of methyl benzoate labelled with $\mathrm{C}^{2} \mathrm{H}_{3}^{-} ; \square, \mathrm{CH}_{3} \mathrm{Cl}$ released by mycelia.

A convincing biochemical explanation of this subtle regulation of both the methylating system and the rate of $\mathrm{CH}_{3} \mathrm{Cl}$ biosynthesis by benzoic acid concentration is not at present possible. The almost complete inhibition of benzoic acid methylation at concentrations above $3 \mathrm{mM}$ may represent a means of directing benzoic acid into alternative metabolic pathways at certain stages of growth. Alternatively, it may act as a regulator of aromatic acid biosynthesis by leading to the accumulation in the mycelium of benzoic acid, which then represses an early stage in its biosynthesis. It is perhaps significant that Harper et al. (1989) noted a dramatic fall in the methyl benzoate pool in cultures in the later stages of growth, which was only reversed as maximum growth was achieved. This decline was not, however, accompanied by any reduction in the amount of methylating enzyme present, and therefore may reflect a real decrease in the rate of methyl benzoate biosynthesis consequent on accumulation of benzoic acid in the medium. Resumption of the biosynthesis of methyl 


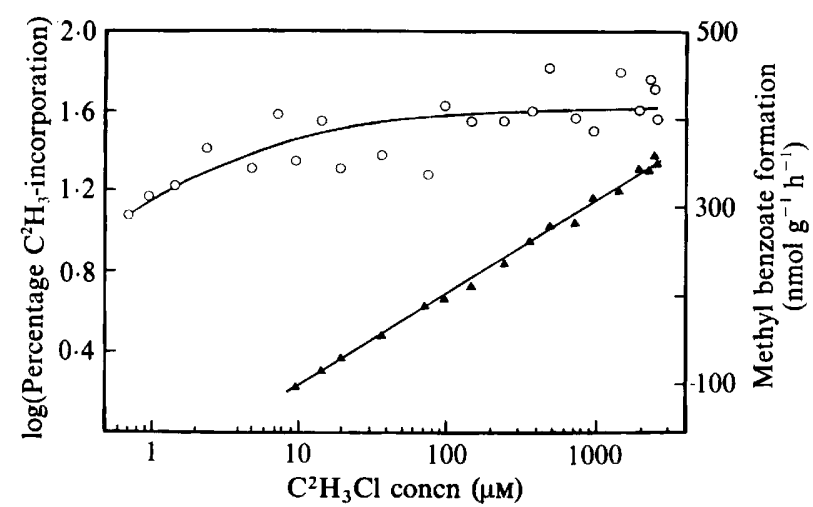

Fig. 3. Effect of exogenous $\mathrm{C}^{2} \mathrm{H}_{3} \mathrm{Cl}$ concentration on methyl benzoate formation and incorporation of $\mathrm{C}^{2} \mathrm{H}_{3}$-label into ester in washed mycelia of $\boldsymbol{P}$. pomaceus. Washed mycelia were incubated as described in Methods with benzoic acid (0.5 mM) and concentrations of $\mathrm{C}^{2} \mathrm{H}_{3} \mathrm{Cl}$ between $0.7 \mu \mathrm{M}$ and $2.5 \mathrm{mM}$. Methyl benzoate formation and incorporation of $\mathrm{C}^{2} \mathrm{H}_{3}$-label into ester was measured after $12 \mathrm{~h}$. O, Methyl benzoate production; $\Delta$, logarithm of the percentage of methyl benzoate labelled with $\mathrm{C}^{2} \mathrm{H}_{3}$ -

benzoate would presumably only occur when the pool of benzoic acid had been utilized by other biochemical pathways. It is pertinent to note that neither methyl butyrate nor methyl benzoate exhibited significant feedback inhibition of methylation at the concentrations at which they normally accumulated in culture medium or in which they were present in the assay procedure, i.e. $<0 \cdot 15 \mathrm{mM}$.

\section{Effect of exogenous $\mathrm{C}^{2} \mathrm{H}_{3} \mathrm{Cl}$ and $\mathrm{C}^{2} \mathrm{H}_{3} \mathrm{Br}$ concentration on ester biosynthesis and $\mathrm{C}^{2} \mathrm{H}_{3}$-incorporation}

With 2 mm-butyric acid as substrate, a linear relationship $(r=0.994, P<0.001)$ was found between the logarithm of the percentage $\mathrm{C}^{2} \mathrm{H}_{3}$-incorporation and the logarithm of exogenous $\mathrm{C}^{2} \mathrm{H}_{3} \mathrm{Cl}$ concentration over the concentration range examined $(0.75 \mu \mathrm{M}$ to $2.5 \mathrm{mM})$, the interdependence being defined by equation (1).

$$
\begin{aligned}
& \log \left(\% \mathrm{C}^{2} \mathrm{H}_{3} \text {-incorp. }\right) \\
& \quad=\log 0.56+0.58 \log \left(\mathrm{C}^{2} \mathrm{H}_{3} \mathrm{Cl} \text { concn }\right)
\end{aligned}
$$

As previously mentioned, the overall rate of methyl butyrate biosynthesis is not significantly affected by the concentration of exogenous $\mathrm{C}^{2} \mathrm{H}_{3} \mathrm{Cl}$, so the nature of the relationship between the absolute amount of $\mathrm{C}^{2} \mathrm{H}_{3^{-}}$ labelled ester synthesized and $\mathrm{C}^{2} \mathrm{H}_{3} \mathrm{Cl}$ concentration must be of the same form as equation (1) above.

The effect of exogenous $\mathrm{C}^{2} \mathrm{H}_{3} \mathrm{Cl}$ concentration on $\mathrm{C}^{2} \mathrm{H}_{3}$-incorporation into methyl benzoate by washed mycelia in the presence of $0.5 \mathrm{~mm}$-benzoic acid is illustrated in Fig. 3. Incorporation was too low to record accurately by the mass spectrometric technique at concentrations of $\mathrm{C}^{2} \mathrm{H}_{3} \mathrm{Cl}$ below $10 \mu \mathrm{M}$, so measurements of this parameter were confined to the range $10 \mu \mathrm{M}$ to $2.5 \mathrm{mM}$. As with butyric acid as methyl acceptor a linear relationship ( $r=0.998, P<0.001)$ was observed between the logarithm of percentage $\mathrm{C}^{2} \mathrm{H}_{3}$-incorporation into methyl ester and the logarithm of $\mathrm{C}^{2} \mathrm{H}_{3} \mathrm{Cl}$ concentration. In this case the relationship conformed to equation (2).

$$
\begin{aligned}
& \log \left(\% \mathrm{C}^{2} \mathrm{H}_{3} \text {-incorp. }\right) \\
& \quad=\log 0.56+0.47 \log \left(\mathrm{C}^{2} \mathrm{H}_{3} \mathrm{Cl} \text { concn }\right)
\end{aligned}
$$

In contrast to the situation with butyric acid as methyl acceptor, methyl ester biosynthesis is stimulated by increased $\mathrm{C}^{2} \mathrm{H}_{3} \mathrm{Cl}$ concentration up to approximately $10 \mu \mathrm{M}$. However, the methylation system appears to be effectively saturated with $\mathrm{C}^{2} \mathrm{H}_{3} \mathrm{Cl}$ above this concentration and the dependence of the absolute amount of $\mathrm{C}^{2} \mathrm{H}_{3}$-labelled ester formed on $\mathrm{C}^{2} \mathrm{H}_{3} \mathrm{Cl}$ concentration must again be of a similar form to (2) above.

This relationship is identical to the empirical Freundlich adsorption isotherm (3) frequently employed to predict adsorption from the gaseous phase or solution at solid surfaces (Glasstone \& Lewis, 1960).

$$
\begin{aligned}
a & =k c^{n} \\
\text { i.e. } \log a & =\log k+n \log c
\end{aligned}
$$

where $a$ is the amount of solute adsorbed, $c$ is the concentration of solute, and $n$ and $k$ are constants for the given adsorbent and adsorbate.

This similarity suggests that exogenous $\mathrm{C}^{2} \mathrm{H}_{3} \mathrm{Cl}$ competes with endogenously synthesized $\mathrm{CH}_{3} \mathrm{Cl}$ at a solid interface (possibly a membrane within the cell) prior to reaction at the active site and that percentage incorporation of exogenous $\mathrm{C}^{2} \mathrm{H}_{3}$ - into ester is governed by the relative concentrations of labelled and unlabelled compound adsorbed at the interface. The amount of unlabelled compound adsorbed will be dependent at a particular stage of growth on the rate of endogenous $\mathrm{CH}_{3} \mathrm{Cl}$ biosynthesis, which has previously been shown to be determined by $(a)$ the nature of the methyl acceptor (Harper et al., 1989) and (b) its concentration (see above). However, with a known concentration of a given methyl acceptor substrate, the rate of endogenous $\mathrm{CH}_{3} \mathrm{Cl}$ synthesis and presumably adsorption at the interface will be constant. Hence, the rate of $\mathrm{C}^{2} \mathrm{H}_{3}$-incorporation will be dependent on the adsorption of $\mathrm{C}^{2} \mathrm{H}_{3} \mathrm{Cl}$, which will vary with the exogenous $\mathrm{C}^{2} \mathrm{H}_{3} \mathrm{Cl}$ concentration as predicted by the adsorption isotherm.

When $\mathrm{C}^{2} \mathrm{H}_{3} \mathrm{Cl}$ was replaced by $\mathrm{C}^{2} \mathrm{H}_{3} \mathrm{Br}$ as methyl donor with $2 \mathrm{~mm}$-butyric acid as substrate, methyl butyrate synthesis remained at a plateau level at concentrations up to $100 \mu \mathrm{M}$ and the methylating system was clearly saturated with the halomethane (Fig. 4). At higher concentrations ester biosynthesis fell sharply, almost certainly as a result of the toxic effects of 


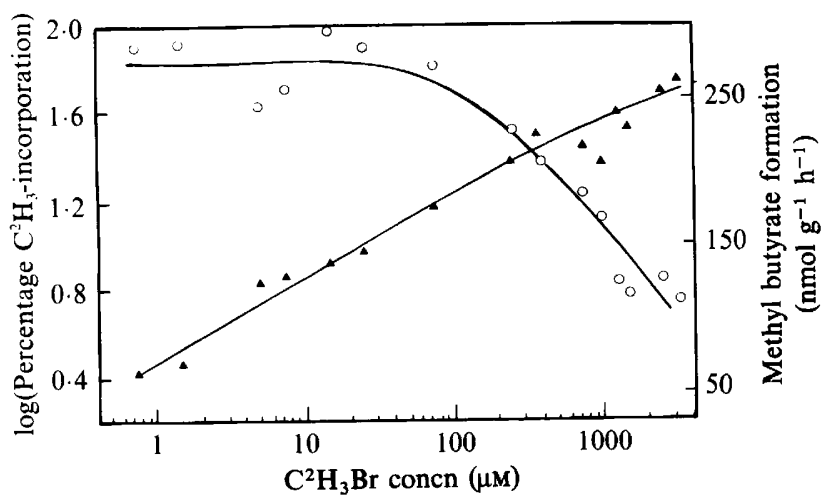

Fig. 4. Effect of exogenous $\mathrm{C}^{2} \mathrm{H}_{3} \mathrm{Br}$ concentration on methyl butyrate formation and incorporation of $\mathrm{C}^{2} \mathrm{H}_{3}$-label into ester in washed mycelia of $P$. pomaceus. Washed $\mathrm{Br}^{-}$-grown mycelia were incubated as described in Methods with butyric acid ( $2 \mathrm{~mm})$ and concentrations of $\mathrm{C}^{2} \mathrm{H}_{3} \mathrm{Br}$ between $0.7 \mu \mathrm{M}$ and $3 \mathrm{~mm}$. Methyl butyrate formation and incorporation of $\mathrm{C}^{2} \mathrm{H}_{3}$-label into ester was measured after $12 \mathrm{~h}$. $O$, Methyl butyrate production; $\boldsymbol{\Delta}$, logarithm of the percentage of methyl butyrate labelled with $\mathrm{C}^{2} \mathrm{H}_{3}$.

bromomethane on metabolic processes in general. Nevertheless, in the $\mathrm{C}^{2} \mathrm{H}_{3} \mathrm{Br}$ concentration range over which the rate of methyl ester biosynthesis is reasonably constant, the relationship between $\mathrm{C}^{2} \mathrm{H}_{3}$-incorporation and the concentration of exogenous $\mathrm{C}^{2} \mathrm{H}_{3} \mathrm{Br}$ conforms to equation (3), with $k=3.05$ and $n=0.38 \quad(r=0.978$, $P<0.001$ ).

In summary, these results tend to favour location of the $\mathrm{CH}_{3} \mathrm{Cl}$-biosynthesizing enzyme and the $\mathrm{CH}_{3} \mathrm{Cl}$-utilizing methylation system on either side of a membrane within the cell through which $\mathrm{CH}_{3} \mathrm{Cl}$ diffuses to the active site. This scheme is quite compatible with the multienzyme complex postulated by Harper et al. (1989) in that both enzymes may well be physically associated with the membrane. Indeed, the breakdown in channelling and accompanying release of gaseous $\mathrm{CH}_{3} \mathrm{Cl}$ by the fungus in the later stages of growth may represent the progressive dissociation of the $\mathrm{CH}_{3} \mathrm{Cl}$-biosynthesizing enzyme from the membrane.

\section{Effect of different exogenous $\mathrm{C}^{2} \mathrm{H}_{3}$-labelled halomethanes on ester biosynthesis and $\mathrm{C}^{2} \mathrm{H}_{3}$-incorporation into ester}

Table 1 shows the effects of exogenous $\mathrm{C}^{2} \mathrm{H}_{3}$-labelled chloro-, bromo- and iodomethane on ester formation and $\mathrm{C}^{2} \mathrm{H}_{3}$-incorporation into ester in washed mycelia grown in the presence of different halide ions. The expresson of results on a dry wt rather than the fresh wt basis hitherto employed was found necessary because mycelial fresh $\mathrm{wt} / \mathrm{dry}$ wt ratios appeared to depend on the nature of the halide ion in the growth medium, varying from 3.6 for
Table 1. Effect of different exogenous $\mathrm{C}^{2} \mathrm{H}_{3}$-labelled halomethanes on ester formation and $\mathrm{C}^{2} \mathrm{H}_{3}$-incorporation into ester in $P$. pomaceus grown in presence of different halide ions

Washed mycelia were from cultures grown as described in Methods.

\begin{tabular}{cccc}
\hline \hline \multirow{2}{*}{$\begin{array}{c}\text { Exogenous } \\
\mathrm{C}^{2} \mathrm{H}_{3} \text {-labelled } \\
\text { halomethane } \\
(0 \cdot 25 \mathrm{mM})\end{array}$} & $\begin{array}{c}\text { Methyl butyrate formed }\left(\mathrm{nmol} \mathrm{g}^{-1} \mathrm{~h}^{-1} \pm \mathrm{SD}\right) \\
{\left[\% \text { Ester labelled with } \mathrm{C}^{2} \mathrm{H}_{3^{-}}, \pm \mathrm{SD}\right]}\end{array}$ \\
\cline { 2 - 4 } & $\begin{array}{c}\mathrm{C} \mathbf{l}^{-} \text {-grown } \\
\text { mycelia }\end{array}$ & $\begin{array}{c}\mathrm{Br}^{-} \text {-grown } \\
\text { mycelia }\end{array}$ & $\begin{array}{c}\mathrm{I}^{-} \text {-grown } \\
\text { mycelia }\end{array}$ \\
\hline $\mathrm{C}^{2} \mathrm{H}_{3} \mathrm{Cl}$ & $498 \pm 57$ & $1453 \pm 196$ & $1265 \pm 198$ \\
& {$[24 \pm 7]$} & {$[5 \pm 2]$} & {$[3 \pm 1]$} \\
$\mathrm{C}^{2} \mathrm{H}_{3} \mathrm{Br}$ & $565 \pm 91$ & $1311 \pm 123$ & $700 \pm 144$ \\
& {$[42 \pm 2]$} & {$[34 \pm 4]$} & {$[21 \pm 4]$} \\
$\mathrm{C}^{2} \mathrm{H}_{3} \mathrm{I}$ & $540 \pm 71$ & $1125 \pm 266$ & $783 \pm 169$ \\
& {$[44 \pm 6]$} & {$[23 \pm 5]$} & {$[11 \pm 3]$} \\
\hline \hline
\end{tabular}

$\mathrm{Cl}^{-}$-grown cells to 5.6 and 5.9 for $\mathrm{Br}^{-}$- and $\mathrm{I}^{-}$-grown cells respectively.

More methyl butyrate was formed by mycelia from cultures grown with $\mathrm{Br}^{-}$and $\mathrm{I}^{-}$as compared with $\mathrm{Cl}^{-}$. Whether this greater activity of the methylating system can be attributed to induction of more enzyme or higher turnover rates with $\mathrm{CH}_{3} \mathrm{Br}$ or $\mathrm{CH}_{3} \mathrm{I}$ as substrate is not known. However, this finding may help to explain the accumulation of methyl benzoate in $\mathrm{I}^{-}$-grown cultures reported by Harper \& Kennedy (1986). Incorporation of $\mathrm{C}^{2} \mathrm{H}_{3}$ - from exogenous $\mathrm{C}^{2} \mathrm{H}_{3} \mathrm{Cl}$ in $\mathrm{Br}^{-}$- and $\mathrm{I}^{-}$-grown mycelia was very much less than that for $\mathrm{Cl}^{-}$-grown mycelia, an observation which can be interpreted in terms of the methylating system possessing a higher affinity for endogenous $\mathrm{CH}_{3} \mathrm{Br}$ and $\mathrm{CH}_{3} \mathrm{I}$ than for exogenous $\mathrm{C}^{2} \mathrm{H}_{3} \mathrm{Cl}$.

When $\mathrm{Cl}^{-}$-grown mycelia were incubated with exogenous $\mathrm{C}^{2} \mathrm{H}_{3}$-labelled bromo- or iodomethane a slight enhancement of ester formation was observed compared with mycelia incubated with $\mathrm{C}^{2} \mathrm{H}_{3} \mathrm{Cl}$ but $\mathrm{C}^{2} \mathrm{H}_{3}$-incorporation almost doubled, suggesting yet again that the methylating system has a higher affinity for $\mathrm{C}^{2} \mathrm{H}_{3} \mathrm{Br}$ and $\mathrm{C}^{2} \mathrm{H}_{3} \mathrm{I}$ than for $\mathrm{C}^{2} \mathrm{H}_{3} \mathrm{Cl}$. When exogenous labelled halomethane was incubated with mycelia grown in the presence of the corresponding halide ion, the superiority of $\mathrm{CH}_{3} \mathrm{Br}$ as a substrate for the methylating system was clearly visible. Ester production was considerably higher and incorporation markedly increased with $\mathrm{Br}^{-}$-grown cells incubated with exogenous $\mathrm{C}^{2} \mathrm{H}_{3} \mathrm{Br}$ compared with $\mathrm{Cl}^{-}$- and $\mathrm{I}^{-}$-grown cells incubated with $\mathrm{C}^{2} \mathrm{H}_{3} \mathrm{Cl}$ and $\mathrm{C}^{2} \mathrm{H}_{3} \mathrm{I}$ respectively. Harper et al. (1989) found reduced rates of methylation in $\mathrm{Br}^{-}$-grown cells incubated with $\mathrm{C}^{2} \mathrm{H}_{3} \mathrm{Br}$ compared with $\mathrm{Cl}^{-}$-grown cells incubated with 
$\mathrm{C}^{2} \mathrm{H}_{3} \mathrm{Cl}$, but the relatively high $(1.23 \mathrm{~mm})$ halomethane concentration used would have led to severe toxic effects in the $\mathrm{C}^{2} \mathrm{H}_{3} \mathrm{Br}$-treated mycelia reducing the yield of methylated product (see Fig. 4). Similarly, the apparent reduction in ester yields evident in Table 1 in experiments with mycelia grown in the presence of $\mathrm{I}^{-}$and incubated with $\mathrm{C}^{2} \mathrm{H}_{3} \mathrm{Br}$ or $\mathrm{C}^{2} \mathrm{H}_{3} \mathrm{I}$ can be attributed to the additive deleterious effects of growth in the presence of toxic halide ion and incubation with toxic halomethane.

Harper \& Kennedy (1986) showed that growth of $P$. pomaceus in the presence of $\mathrm{F}^{-}$did not lead to the biosynthesis of fluoromethane $\left(\mathrm{CH}_{3} \mathrm{~F}\right)$. That observation does not eliminate the possibility that $\mathrm{CH}_{3} \mathrm{~F}$ may act as a methyl donor for methylation of ester. Accordingly, the effect of $\mathrm{C}^{2} \mathrm{H}_{3} \mathrm{~F}$ on methyl butyrate biosynthesis in washed mycelia incubated with butyric acid was examined. At concentrations between 0.2 and $1.2 \mathrm{mM}$, exogenous $\mathrm{C}^{2} \mathrm{H}_{3} \mathrm{~F}$ had no significant effect on the rate of methylation by mycelia. No incorporation of $\mathrm{C}^{2} \mathrm{H}_{3}$ from $\mathrm{C}^{2} \mathrm{H}_{3} \mathrm{~F}$ into ester was noted. Therefore, $\mathrm{CH}_{3} \mathrm{~F}$ acts neither as a methyl donor nor as a competitive inhibitor of the utilization of endogenously synthesized $\mathrm{CH}_{3} \mathrm{Cl}$.

\section{References}

Collins, R. P. \& Halim, A. F. (1972). An analysis of odorous constituents produced by various species of Phellinus. Canadian Journal of Microbiology 18, 65-66.

Cowan, M. I., Glen, A. T., Hutchinson, S. A., Macartney, M. E., Mackintosh, J. M. \& Moss, A. M. (1973). Production of volatile metabolites by species of Fomes. Transactions of the British Mycological Society 60, 347-360.

Glasstone, S. \& LeWIS, D. (1960). Elements of Physical Chemistry, 2nd edn, pp. 558-567. London: MacMillan.

HARPER, D. B. (1985). Halomethane from halide ion - a highly efficient fungal conversion of environmental significance. Nature, London $315,55-57$.

HaRPER, D. B. \& Hamilton, J. T. G. (1988). Biosynthesis of chloromethane in Phellinus pomaceus. Journal of General Microbiology 134, 2831-2839.

HARPER, D. B. \& KENNEDY, J. T. (1986). Effect of growth conditions on halomethane production by Phellinus species: biological and environmental implications. Journal of General Microbiology 132, 1231-1246.

HARPER, D. B., KenNedy, J. T. \& Hamilton, J. T. G. (1988). Chloromethane biosynthesis in poroid fungi. Phytochemistry 27, 3147-3153

HaRPER, D. B., Hamilton, J. T. G., KenNedy, J. T. \& MCNally, K. J. (1989). Chloromethane, a novel methyl donor for biosynthesis of esters and anisoles in Phellinus pomaceus. Applied and Environmental Microbiology 55, 1981-1989. 